\title{
Kudos Redux
}

Correspondence for Reference \& User Services Quarterly should be addressed to Editor Diane Zabel, Schreyer Business Library, The Pennsylvania State University, 309 Paterno Library, University Park, PA 16802; e-mail:dxz2@psu.edu. am using this space to once again thank all the individuals who contributed to the production of RUSQ during the past year. Members of the RUSQ Editorial Advisory Board strive to provide meaningful and constructive feedback to authors. The 2008-09 board was composed of Judith M. Arnold, Gwen Arthur, Corinne Hill, Jessica E. Moyer, Kjerstine Nielsen, Lisa O'Connor, Amber A. Prentiss, Marianne Ryan, Michael Stephens, and Molly Strothmann. When my inbox is overflowing with manuscript submissions, I sometimes call upon other experts to serve as referees. I am grateful to the following occasional reviewers who stepped in to lend a hand this past year: Rebecca Albitz, Christine Avery, Susan Beck, Anne Behler, Ellysa Stern Cahoy, Phillip Edwards, Linda Friend, Jennifer Gilley, Kevin Harwell, Nancy Huling, Daniel Mack, Cheryl McCallips, Bonnie Osif, John Riddle, Emily Rimland, Matthew Wayman, Beth S. Woodard, and Carol Wright. The guidance provided by all of these dedicated reviewers helped produce a collection of high-quality feature articles. The following peer-reviewed feature articles were published in volume 48 :

"Preference for Reference: New Options and Choices for Academic Library Users," by Diane Granfield and Mark Robertson.

"Reference Desk Staffing Trends: A Survey," by Julia Banks and Carl Pracht.

"Don't Shelve the Questions: Defining Good Customer Service for Shelvers," by Luke Vilelle and Christopher C. Peters.

"Subject Searching Success: Transaction Logs, Patron Perceptions, and Implications for Library Instruction," by Karen Antell and Jie Huang.

"Using Continuous Quality Improvement Methods to Evaluate Library Service Points," by Merrill Stein, Teresa Edge, John M. Kelley, Dane Hewlett, and James F. Trainer.

"Overcoming Transactional Distance: Instructional Intent in an E-mail Reference Service," by Martha Portree, R. Sean Evans, Tina M. Adams, and John J. Doherty.

"Volunteers in Libraries: Program Structure, Evaluation and Theoretical Analysis," by Erica A. Nicol and Corey M. Johnson.

"Use of Public Libraries by Immigrants," by Susan K. Burke. 


\section{FROM THE EDITOR}

"Whose Decline?: Which Academic Libraries are 'Deserted' in Terms of Reference Transactions?" by Rachel Applegate.

"Developing a Model for Reference Research Statistics: Applying the 'Warner Model' of Reference Question Classification to Streamline Research Services," by Harry C. Meserve, Sandra E. Belanger, Joan Bowlby, and Lisa Rosenblum.

"Exploring Academic Library Users' Preferences of Delivery Methods for Library Instruction: Webpage, Digital Game, and Other Modalities," by Michael J. Robertson and James G. Jones.

"Uncovering Black Feminist Writers 1963-90: An Evaluation of Their Coverage in Research Tools," by Rebecca Hankins.

"Making Unmediated Access to E-Resources a Reality: Creating a Usable ERM Interface," by Kate Fuller, Jill Livingston, Stephanie Willen Brown, Susanna Cowan, Thomas Wood, and Leslie Porter.

"Perception and Use of PowerPoint at Library Instruction Conferences," by David J. Brier and Vickery Kaye Lebbin.

"Promoting Library Reference Services to First-Year Undergraduate Students: What Works?" by Karen Sobel.

"Reference Classification-Is it Time to Make Some Changes?" by Tina M. Neville and Deborah B. Henry.

"Retaining Intellectual Capital: Retired Faculty and Academic Libraries," by Karen A. Hartman.

"Creating a Digital Archive for Students' Research in a Credit Library Course," by Tiffany R. Walsh and Christopher V. Hollister.

I invited several prominent individuals to contribute guest editorials on important developments, interesting trends, or model practices relating to reference and public services librarianship. Robert H. Kieft, general editor of the new ALA Guide to Reference wrote about the transformation of this classic tool. Marie L. Radford's blueprint for reference service excellence generated a lot of buzz at the 2009 ALA Midwinter Meeting. Ellysa Stern Cahoy and Loanne Snavely demonstrated how libraries can utilize data from national environmental scans and local surveys for assessment and planning purposes.

Neal Wyatt did double duty. As 2008-09 RUSA President she contributed columns on RUSA's values, traditions, activities, and initiatives. She also edited "The Alert Collector" column. This past year, the column provided advice on building collections relating to criminal justice administration and criminology (Richard A. Stoddart, Brett Spencer, and Adrienne R. McPhaul); American presidential power (Amalia
L. Monroe); and global warming (Denise A. Brush). A genrerelated column was also published, this one highlighting core collections in fantasy fiction (Charlotte Burcher, Neil Hollands, Andrew Smith, Barry Trott, and Jessica Zellers).

The "Readers' Advisory" column, edited by Barry Trott, has a loyal readership. Columns in this past volume highlighted the success of the Johnson County (Kans.) Library's Book Club to Go Kits (Virginia Hermes, Mary Anne Hile, and Johnetta L. Frisbie), Barry Trott's reflections on the future of readers' advisory, Kaite Mediatore Stover's insights on the value of social networking sites for readers' advisory, and Julie Elliott's research findings relating to barriers to leisure reading promotion in academic libraries.

M. Kathleen Kern wrote about personal experiences in her role as editor of the "Accidental Technologist" column. One column provided a fascinating account of her month-long work exchange at the Shanghai Library. Her second column focused on teaching reference, weaving in her recent experience as the instructor for an online course offered by Rutgers University.

As usual, Judith M. Nixon recruited authors to write on timely topics for the "Management" column that she ably edits. Mitchell J. Fontenot wrote about the challenges (and rewards) of mid-career job changes, and David Shumaker focused on the managerial issues relating to the growing practice of embedded librarianship.

In this past volume, the "For Your Enrichment" column featured a new professional's perspective on workplace stress experienced by reference librarians (Marcella KnibbeHaanstra), an article on the implications of changes made to a widely used citation style (Leslie A. Lewis), and survey findings on innovative and best practices in business libraries and centers (Adriana Trujillo Gonzalez, Vincci Kwong, Julie Strange, and Julie Yen).

Lori Arp and Beth S. Woodard have concluded their distinguished service as editors of the "Information Literacy and Instruction" column. Under their editorship, this column has come to be regarded as the source to go to for reflective articles on information literacy instruction. In June 2008, Lori and Beth learned that the 2007 column (46:3) contributed by Craig Gibson on the topic of information literacy and information technology fluency was named one of "LIRT's Top 20 for 2008." This is an extraordinary accomplishment, since these ten articles were culled from more than three hundred articles.

Carolyn A. Radcliff is also stepping down with the conclusion of this volume. She has flawlessly edited the Reference Books section of "Sources" since 2000. Karen Antell will continue her excellent work as the editor of the "Professional Materials" section of "Sources." Both Carolyn and Karen have highlighted the important work that reviewers contribute to the profession. While I would like to thank all those individuals who contributed book reviews to "Sources" this past year, I would like to recognize a special group of reviewers. The following individuals reached the achievement of writ-

CONTINUED ON PAGE 329 